Ihtiyath Vol. 2 No. 2 Desember 2018

\title{
ANALISIS TINGKAT KESEHATAN BANK DENGAN MENGGUNAKAN PENDEKATAN RGEC (RISK PROFILE, GOOD CORPORATE GOVERNANCE, EARNINGS, CAPITAL) (Studi pada PT. Bank Rakyat Indonesia, Tbk Periode 2013-2017)
}

\author{
Meutia Dewi \\ Fakultas Ekonomi, Universitas Samudra \\ meutiadewi@unsam.ac.id
}

\begin{abstract}
ABSTRAK
Penelitian ini bertujuan untuk mengetahui tingkat kesehatan bank pada PT. Bank Rakyat Indonesia, Tbk yang dilihat dari faktor risk profile, good corporate governance, earning, dan capital selama periode 2013-2017. Metode analisis data dalam penelitian ini adalah analisis deskriptif dengan pendekatan kuantitatif. Dalam hasil analisis data dapat dijelaskan bahwa tingkat kesehatan bank pada PT. Bank Rakyat Indonesia, Tbk dilihat dari faktor risk profile menunjukkan NPL bank dibawah $2 \%$ yang berpredikat sangat sehat dan mayoritas LDR bank berpredikat cukup sehat. Faktor good corporate governance menunjukkan bank mendapat predikat sangat terpercaya. Faktor earning menunjukkan ROA bank lebih dari 1,5\% yang berpredikat sangat sehat dan NIM bank lebih dari 3\% yang berpredikat sangat sehat. Faktor capital menunjukkan CAR bank lebih dari 12\% yang berpredikat sangat sehat. Sehingga penilaian tingkat kesehatan bank pada PT. Bank Rakyat Indonesia, Tbk dilihat dari faktor risk profile, good corporate governance, earning, dan capital selama periode 2013-2017 dengan nilai rata-rata sebesar 93,99\% termasuk kedalam kategori "Sangat Sehat" atau peringkat komposit 1 (PK-1).
\end{abstract}

Kata Kunci risk profile, good corporate governance, earning, capital

\section{ABSTRACT}

This study aims to determine the soundness of the bank at PT. Bank Rakyat Republik, Tbk which is seen from risk profile factors, good corporate governance, earnings, and capital during the period 2013-2017. The method of data analysis in this study is descriptive analysis with a quantitative approach. In the results of data analysis, it can be explained that the soundness of the bank at PT. Bank Rakyat Indonesia, Tbk, judging from the risk profile factor, shows that the bank's NPL below $2 \%$ with a very healthy predicate and the majority of bank LDR predicate is quite healty. The factor of good corporate governance shows that the bank has a very trusted title. The earnings factor shows that bank ROA of more than $1.5 \%$ with a very healthy predicate and bank NIM of more than 3\% with a very healthy predicate. The capital factor shows that the bank CAR of more than $12 \%$ has a ver healthy predicate. So that the assessment of the soundness of the bank at PT. Bank Rakyat Indonesia, Tbk seen fromrisk profile factors, good corporate governance, earnings, and capital during the period 
Meutia Dewi: Analisis Tingkat Kesehatan Bank 2013-2017 with an average value of 93,99\% included in the category of "Very Healthy" or composite rating 1 (PK-1)

Keywords: Risk Profile, Good Corporate Governance, Earning, Capital.

\section{PENDAHULUAN}

Salah satu aktivitas perekonomian yang memiliki peranan penting didalam dunia keuangan adalah lembaga perbankan. Peranan penting yang dimiliki perbankan salah satunya yaitu menghimpun dana dari masyarakat dan menyalurkan kembali dana kepada masyarakat. Bank merupakan lembaga keuangan yang aktivitasnya mengandalkan kepercayaan dari nasabahnya. Kepercayaan nasabah tersebut merupakan faktor utama dalam melaksanakan aktivitas perbankan. Untuk menjaga kepercayaan nasabah terhadap dana yang telah mereka percayakan kepada bank, maka manajemen bank harus selalu dalam keadaan sehat dan baik. Bank harus dipelihara kesehatannya dengan cara tetap menjaga likuiditas aset-aset yang dimilikinya sehingga bank tersebut dapat memenuhi kewajibannya serta dapat menjaga kinerjanya dengan optimal agar tetap dipercaya oleh nasabah.

Perbankan harus dikelola dengan semaksimal mungkin agar selalu memperoleh keuntungan dan terhindar dari segala bentuk kerugian. Kerugian yang dialami perbankan dapat berpengaruh terhadap kesehatan bank itu sendiri. Bank yang tidak sehat bukan hanya membahayakan perbankan itu sendiri tetapi juga membahayakan pihak-pihak terkait lainnya. Sehingga Bank Indonesia selaku lembaga pengawas bank mengeluarkan kebijakan penilaian tingkat kesehatan bank berdasarkan Peraturan Bank Indonesia No.6/10/ PBI//2004 tentang Penilaian Tingkat Kesehatan Bank Umum dengan metode CAMELS (Capital, Asset Quality, Management, Earning, Liquidity, and Sensitivity to Market Risk).

Seiring dengan meningkatnya perkembangan dunia perbankan serta perubahan dalam penilaian kondisi bank yang diterapkan secara internasional, maka setiap perbankan dituntut harus mampu untuk mengidentifikasi permasalahan sejak dini serta menerapkan manajemen resiko dan good corporate governance. Langkah tersebut dimaksudkan agar perbankan bisa lebih tahan dalam menghadapi krisis. Kemudian Bank Indonesia melakukan penyempurnaan metode penilaian kesehatan terhadap bank umum dengan mengeluarkan kebijakan baru dalam Peraturan Bank Indonesia No.13/1/PBI/2011 tentang Penilaian Kesehatan Bank Umum dengan metode RGEC (Risk Profile, Good Corporate Governance, Earnings, Capital). Surat Edaran Bank Indonesia No.13/24/DPNP/2011 menjelaskan bahwa 
Ihtiyath Vol. 2 No. 2 Desember 2018

bank diwajibkan untuk melakukan penilaian sendiri (self assessment) tingkat kesehatan bank dengan menggunakan pendekatan risiko (Risk-based Bank Rating/ RBBR) dengan cakupan penilaian yang terdiri dari faktor Profil Resiko (Risk Profile), Good Corporate Governance (GCG), Rentabilitas (Earning), dan Permodalan (Capital) untuk menghasilkan peringkat komposit tingkat kesehatan bank.

PT. Bank Rakyat Indonesia (Persero), Tbk merupakan salah satu bank milik pemerintah terbesar dan tertua di Indonesia yang bertujuan untuk menjadi pilihan pertama dalam perbankan transaksional (www.ir-bri.com). Area coverage yang dimiliki BRI sangat luas sehingga mampu menjangkau hingga ke pelosok negeri di Indonesia. Hampir disetiap kabupaten maupun kecamatan di Indonesia terdapat kantor cabang maupun unit BRI. Hal tersebut membuat BRI memiliki kesempatan lebih besar daripada bank lainnya untuk dapat menjadi bank yang memberikan pelayanan jasa terbaik kepada nasabahnya.

Salah satu bentuk pelayanan yang diberikan BRI kepada nasabahnya yaitu dibidang perkreditan yang pada umumnya berupa kredit modal kerja untuk kalangan pengusaha kecil dan menengah keatas. Banyak kalangan yang tertarik mengambil pinjaman kredit pada BRI untuk kepentingan permodalan usahanya dengan persyaratan yang lebih mudah dibandingkan dengan bank lainnya. Sehingga BRI harus mengucurkan dana yang lebih besar untuk pinjaman kredit tersebut. Walaupun demikian, ternyata BRI harus menghadapi masalah serius pada kredit yang diberikannya. BRI memiliki kredit macet paling tinggi diantara bank BUMN lainnya. Kredit macet yang dimiliki BRI terus mengalami kenaikan dari tahun ke tahun. Hal tersebut terjadi karena pada saat pengucuran kredit dilakukan, Account officer tidak melakukan pengecekan pengajuan kredit nasabahnya dengan benar dan sesuai dengan persyaratan yang telah ditentukan. Berikut ini adalah data kredit macet yang dimiliki oleh PT. Bank Rakyat Indonesia, Tbk dari tahun 2013 sampai 2017:

Tabel 1. Kredit Macet PT. Bank Rakyat Indonesia, Tbk

\begin{tabular}{cc}
\hline Tahun & $\begin{array}{c}\text { Kredit Macet } \\
\text { (Dalam jutaan Rupiah) }\end{array}$ \\
\hline 2013 & 3.624 .233 \\
\hline 2014 & 3.974 .665 \\
\hline 2015 & 4.213 .597 \\
\hline 2016 & 4.605 .802 \\
\hline
\end{tabular}




$\frac{2017}{5 \cdot 216.546}$

Secara lebih mendalam, tujuan dari penelitian ini yaitu untuk mengetahui tingkat kesehatan bank pada PT. Bank Rakyat Indonesia, Tbk yang dilihat dari faktor risk profile, good corporate governance, earnings, dan capital selama periode 2013-2017.

\section{TINJAUAN PUSTAKA}

\section{Profil Risiko (Risk Profile)}

Menurut Surat Edaran Bank Indonesia No.13/24/DPNP/2011, profil risiko merupakan penilaian terhadap risiko inheren dan kualitas penerapan manajemen risiko dalam operasional bank yang dilakukan terhadap 8 (delapan) risiko yaitu:

\section{Risiko Kredit}

Risiko kredit adalah risiko akibat kegagalan debitur dan/atau pihak lain dalam memenuhi kewajiban kepada bank. Risiko kredit pada umumnya terdapat pada seluruh aktivitas bank yang kinerjanya bergantung pada kinerja pihak lawan (counterparty), penerbit (issuer), atau kinerja peminjam dana (borrower). Risiko kredit juga dapat diakibatkan oleh terkonsentrasinya penyediaan dana pada debitur, wilayah geografis, produk, jenis pembiayaan, atau lapangan usaha tertentu.

\section{Risiko Pasar}

Risiko pasar adalah risiko pada posisi neraca dan rekening administratif termasuk transaksi derivatif, akibat perubahan dari kondisi pasar, termasuk risiko perubahan harga option. Risiko pasar meliputi antara lain risiko suku bunga, risiko nilai tukar, risiko ekuitas, dan risiko komoditas.

\section{Risiko Suku Bunga}

Risiko Suku Bunga dapat berasal baik dari posisi trading book maupun posisi banking book. Penerapan manajemen risiko untuk risiko ekuitas dan komoditas wajib diterapkan oleh Bank yang melakukan konsolidasi dengan perusahaan anak. Cakupan posisi trading book dan banking book mengacu pada ketentuan Bank Indonesia mengenai kewajiban penyediaan modal minimum dengan memperhitungkan risiko pasar.

\section{Risiko Likuiditas}

Risiko likuiditas adalah risiko akibat ketidakmampuan bank untuk memenuhi kewajiban 
Ihtiyath Vol. 2 No. 2 Desember 2018

yang jatuh tempo dari sumber pendanaan arus kas, dan/atau dari aset likuid berkualitas tinggi yang dapat diagunkan, tanpa mengganggu aktivitas dan kondisi keuangan bank. Risiko ini disebut juga risiko likuiditas pendanaan (funding liquidity risk).

\section{Risiko Liquiditas}

Risiko likuiditas juga dapat disebabkan oleh ketidakmampuan Bank melikuidasi aset tanpa terkena diskon yang material karena tidak adanya pasar aktif atau adanya gangguan pasar (market disruption) yang parah. Risiko ini juga disebut sebagai risiko likuiditas pasar (market liquidity risk). Untuk menghitung risiko likuiditas digunakan rasio Loan to Deposit Ratio (LDR) yaitu rasio yang digunakan untuk menilai tingkat likuiditas suatu bank dengan cara membandingkan antara kredit yang disalurkan dengan dana yang dihimpun dari masyarakat sehingga dapat diketahui kemampuan bank dalam membayar kewajiban jangka pendeknya (SE No.13/24/DPNP/2011).

\section{Risiko Operasional}

Risiko operasional adalah risiko akibat ketidakcukupan dan/atau tidak berfungsinya proses internal, kesalahan manusia, kegagalan sistem, dan/atau adanya kejadian eksternal yang mempengaruhi operasional bank. Sumber risiko operasional dapat disebabkan antara lain oleh sumber daya manusia, proses, sistem, dan kejadian eksternal.

\section{Risiko Hukum}

Risiko hukum adalah risiko yang timbul akibat tuntutan hukum dan/atau kelemahan aspek yuridis. Risiko ini juga dapat timbul antara lain karena ketiadaan peraturan perundang-undangan yang mendasari atau kelemahan perikatan, seperti tidak dipenuhinya syarat sahnya kontrak atau agunan yang tidak memadai.

\section{Risiko Stratejik}

Risiko stratejik adalah risiko akibat ketidaktepatan bank dalam mengambil keputusan dan/atau pelaksanaan suatu keputusan stratejik serta kegagalan dalam mengantisipasi perubahan dalam lingkungan bisnis. Sumber risiko stratejik antara lain ditimbulkan dari kelemahan dalam proses formulasi strategi dan ketidaktepatan dalam perumusan strategi, ketidaktepatan dalam implementasi strategi, dan kegagalan mengantisipasi perubahan lingkungan bisnis. 
Meutia Dewi: Analisis Tingkat Kesehatan Bank

\section{Risiko Kepatuhan}

Risiko kepatuhan adalah risiko yang timbul akibat bank tidak mematuhi dan/atau tidak melaksanakan peraturan perundang-undangan dan ketentuan yang berlaku. Sumber risiko kepatuhan antara lain timbul karena kurangnya pemahaman atau kesadaran hukum terhadap ketentuan maupun standar bisnis yang berlaku umum.

\section{Risiko Reputasi}

Risiko reputasi adalah risiko akibat menurunnya tingkat kepercayaan stakeholder yang bersumber dari persepsi negatif terhadap bank. Salah satu pendekatan yang digunakan dalam mengkategorikan sumber risiko reputasi bersifat tidak langsung (below the line) dan bersifat langsung (above the line).

\section{Good Corporate Governance (GCG)}

Berdasarkan Surat Edaran Bank Indonesia No.15/15/DPNP/2013 tentang pelaksanaan Good Corporate Governance bagi bank umum, menyatakan bahwa bank wajib melaksanakan kegiatan usahanya dengan berpedoman pada prinsip-prinsip GCG untuk melindungi kepentingan para pemangku kepentingan, meningkatkan kepatuhan terhadap peraturan perundang-undangan yang berlaku serta nilai-nilai etika yang berlaku umum pada industri perbankan. Penilaian terhadap faktor GCG dalam metode RBBR didasarkan kedalam tiga aspek utama yaitu, governance structure, governance process, dan governance output. Berdasarkan ketetapan Bank Indonesia yang disajikan dalam Laporan Pengawasan Bank (2012:36): "Governance structure mencakup pelaksanaan tugas dan tanggung jawab Dewan Komisaris dan Dewan Direksi serta kelengkapan dan pelaksanaan tugas komite. Governance process mencakup fungsi kepatuhan bank, penanganan benturan kepentingan, penerapan fungsi audit intern, penyediaan dana kepada pihak terkait dan dana besar, serta rencana strategis bank. Aspek terakhir governance output mencakup transparansi kondisi keuangan dan non keuangan, laporan pelaksanaan GCG yang memenuhi prinsip Transparancy, Accountability, Responsibility, Indepedency, dan Fairness (TARIF)".

\section{Rentabilitas (Earnings)}

Menurut Surat Edaran Bank Indonesia No.13/24/DPNP/2011, penilaian terhadap faktor rentabilitas meliputi evaluasi terhadap kinerja rentabilitas, sumber-sumber rentabilitas, kesinambungan (sustainability) rentabilitas, dan manajemen rentabilitas. Kasmir (2014:327) menyatakan bahwa rentabilitas merupakan aspek yang digunakan untuk mengukur kemampuan bank dalam meningkatkan keuntungan. Kemampuan ini dilakukan da- 
Ihtiyath Vol. 2 No. 2 Desember 2018

lam suatu periode. Kegunaan aspek ini juga untuk mengukur tingkat efisiensi usaha dan profitabilitas yang dicapai bank bersangkutan. Sedangkan menurut Wardiah (2013:284), rentabilitas merupakan rasio yang mengukur efektivitas perusahaan dalam memperoleh laba.

Untuk menghitung rentabilitas digunakan rasio Return on Asset (ROA) dan rasio Net Interest Margin (NIM). ROA merupakan rasio untuk mengukur kemampuan bank menghasilkan laba dengan menggunakan asetnya (PBI No.13/1/PBI/2011). Sedangkan NIM merupakan rasio yang digunakan untuk mengukur kemampuan bank dalam menghasilkan pendapatan bunga bersih atas pengolahan besar aktiva produktif (PBI No.13/1/PBI/2011).

\section{Permodalan (Capital)}

Menurut Surat Edaran Bank Indonesia No.13/24/DPNP/2011, penilaian atas faktor permodalan meliputi evaluasi terhadap kecukupan permodalan dan kecukupan pengelolaan permodalan. Menurut Wardiah (2013:344), modal bank merupakan dana yang diinvestasikan oleh pemilik dana pada waktu pendirian bank yang dimaksudkan untuk membiayai kegiatan usaha bank. Permodalan (capital) merupakan salah satu faktor yang penting bagi bank dalam mengembangkan usahanya dan menampung risiko kerugian. Tingkat kecukupan modal sangat tergantung dari portofolio asetnya. Kecukupan modal merupakan faktor penting bagi bank untuk menata eksposur risiko saat ini dan dimasa yang akan datang.

Rasio yang dapat digunakan untuk mengukur kecukupan modal yang dimiliki bank adalah Capital Adequacy Ratio (CAR). Menurut Wardiah (2013:295), CAR adalah rasio kecukupan modal bank atau kemampuan bank dalam permodalan yang ada untuk menutup kemungkinan kerugian dalam perkreditan atau perdagangan surat-surat berharga. Pada saat ini dengan ketentuan yang berlaku, CAR suatu bank sekurang-kurangnya sebesar $8 \%$.

\section{METODE PENELITIAN Ruang Lingkup Penelitian}

Penelitian ini merupakan bagian dari mata kuliah Manajemen Keuangan. Penelitian ini menganalisis tingkat kesehatan Bank dengan menggunakan pendekatan RGEC pada PT. Bank Rakyat Indonesia, Tbk periode 2013-2017. Waktu penelitian dimulai sejak bulan Februari sampai dengan bulan Juli 2018. 
Meutia Dewi: Analisis Tingkat Kesehatan Bank

\section{Metode Analisis Data}

Metode analisis data yang digunakan adalah analisis deskriptif dengan pendekatan kuantitatif. Metode analisis data pada analisis laporan keuangan dengan menggunakan pendekatan Peraturan Bank Indonesia No.13/1/PBI/2011 tentang penilaian tingkat kesehatan bank umum. Data yang diperoleh pada penelitian ini dianalisa secara deskriptif. Langkah-langkah yang digunakan untuk menilai tingkat kesehatan bank untuk masing-masing faktor dan komponennya adalah sebagai berikut:

Mengumpulkan data dari laporan keuangan perusahaan yang berkaitan dengan variabel penelitian.

Analisis Profil Risiko (Risk Profile), dengan menggunakan 2 indikator yaitu faktor risiko kredit dan faktor risiko likuiditas.

\section{Menghitung Risiko Kredit}

Menurut Surat Edaran Otoritas Jasa Keuangan No.14/SEOJK.03/2017, pengukuran Non Performing Loan (NPL) menggunakan rumus:

$N P L=x 100 \%$

Tabel 2. Matriks Kriteria Peringkat Profil Resiko (NPL)

\begin{tabular}{ccc}
\hline Peringkat & Keterangan & Kriteria \\
\hline 1 & Sangat Sehat & $\mathrm{NPL}<2 \%$ \\
\hline 2 & Sehat & $2 \% \leq \mathrm{NPL}<5 \%$ \\
\hline 3 & Cukup Sehat & $5 \% \leq \mathrm{NPL}<8 \%$ \\
\hline 4 & Kurang Sehat & $8 \% \leq \mathrm{NPL}<12 \%$ \\
\hline 5 & Tidak Sehat & $\mathrm{NPL} \geq 12 \%$ \\
\hline
\end{tabular}

\section{Menghitung Risiko Likuiditas}

Menurut Surat Edaran Otoritas Jasa Keuangan No.14/SEOJK.03/2017. pengukuran Loan to Deposit Ratio (LDR) menggunakan rumus:

$L D R=\times 100 \%$

Tabel 3. Matriks Kriteria Peringkat Profil Resiko (LDR)

\begin{tabular}{ccc}
\hline Peringkat & Keterangan & Kriteria \\
\hline 1 & Sangat Sehat & LDR $\leq 75 \%$ \\
\hline
\end{tabular}


Ihtiyath Vol. 2 No. 2 Desember 2018

\begin{tabular}{ccc}
\hline 2 & Sehat & $75 \%<$ LDR $\leq 85 \%$ \\
\hline 3 & Cukup Sehat & $85 \%<$ LDR $\leq 100 \%$ \\
\hline 4 & Kurang Sehat & $100 \%<$ LDR $\leq 120 \%$ \\
\hline 5 & Tidak Sehat & LDR $>120 \%$ \\
\hline
\end{tabular}

\section{Good Corporate Governance (GCG)}

Indikator penilaian pada Good Corporate Governance (GCG) yaitu menggunakan bobot penilaian berdasarkan nilai komposit dari ketetapan Bank Indonesia menurut Peraturan Bank Indonesia No.13/1/PBI/2011. Good Corporate Governance diukur dengan melihat Coporate Governance Index Perception (CGPI). CGPI merupakan program riset dan pemeringkatan GCG yang memberikan penilaian kualitas Corporate Governance di perusahaan. CGPI diselenggarakan oleh The Indonesian Institute for Corporate Governance (IICG) yang bekerja sama dengan majalah SWA.

Tabel 4. Matriks Kriteria Peringkat Good Corporate Governance (GCG)

\begin{tabular}{|c|c|c|}
\hline Peringkat & Keterangan & Kriteria \\
\hline 1 & Sangat Terpercaya & $85,00-100$ \\
\hline 2 & Terpercaya & $70,00-84,99$ \\
\hline 3 & Cukup Terpercaya & $55,00-69,00$ \\
\hline
\end{tabular}

Analisis Rentabilitas (Earning) Menghitung Return on Asset (ROA)

Menurut Surat Edaran Otoritas Jasa Keuangan No.14/SEOJK.03/2017, perhitungan Return on Asset (ROA) menggunakan rumus:

$$
R O A=x 100 \%
$$

Tabel 5 `Matriks Kriteria Peringkat Rentabilitas (ROA)

\begin{tabular}{|c|c|c|}
\hline Peringkat & Keterangan & Kriteria \\
\hline 1 & Sangat Sehat & $\mathrm{ROA}>1,5 \%$ \\
\hline 2 & Sehat & $1,25 \%<R O A \leq 1,5 \%$ \\
\hline 3 & Cukup Sehat & $0,5 \%<R O A \leq 1,25 \%$ \\
\hline 4 & Kurang Sehat & $0 \%<\mathrm{ROA} \leq 0,5 \%$ \\
\hline 5 & Tidak Sehat & $\mathrm{ROA} \leq 0 \%$ \\
\hline
\end{tabular}

Menghitung Net Interest Margin (NIM)

Menurut Surat Edaran Otoritas Jasa Keuangan No.14/SEOJK.03/2017, perhitungan Net Interest Margin (NIM) menggunakan rumus:

$$
N I M=\times 100 \%
$$


Meutia Dewi: Analisis Tingkat Kesehatan Bank

Tabel 6. Matriks Kriteria Peringkat Rentabilitas (NIM)

\begin{tabular}{|c|c|c|}
\hline Peringkat & Keterangan & Kriteria \\
\hline 1 & Sangat Sehat & $\mathrm{NIM}>3 \%$ \\
\hline 2 & Sehat & $2 \%<\mathrm{NIM} \leq 3 \%$ \\
\hline 3 & Cukup Sehat & $1,5 \%<N I M \leq 2 \%$ \\
\hline 4 & Kurang Sehat & $1 \%<\mathrm{NIM} \leq 1,5 \%$ \\
\hline 5 & Tidak Sehat & $\mathrm{NIM} \leq 1 \%$ \\
\hline
\end{tabular}

\section{Analisis Permodalan (Capital)}

\section{Menghitung Capital Adequacy Ratio (CAR)}

Menurut Surat Edaran Otoritas Jasa Keuangan No.14/SEOJK.03/2017, rasio CAR menggunakan rumus:

$$
C A R=\times 100 \%
$$

Tabel 7. Matriks Kriteria Peringkat Permodalan (CAR)

\begin{tabular}{ccc}
\hline Peringkat & Keterangan & Kriteria \\
\hline 1 & Sangat Sehat & CAR $>12 \%$ \\
\hline 2 & Sehat & $9 \% \leq$ CAR $<12 \%$ \\
\hline 3 & Cukup Sehat & $8 \% \leq$ CAR $<9 \%$ \\
\hline 4 & Kurang Sehat & $6 \%<$ CAR $<8 \%$ \\
\hline 5 & Tidak Sehat & CAR $\leq 6 \%$ \\
\hline
\end{tabular}

Melakukan pemeringkatan masing-masing analisis NPL, LDR, GCG, ROA, NIM dan CAR. Menetapkan peringkat komposit penilaian tingkat kesehatan bank dari tahun 2013 sampai 2017. Nilai komposit untuk rasio keuangan masing-masing komponen yang menempati peringkat komposit akan bernilai sebagai berikut:

Peringkat 1 = Setiap kali ceklist dikalikan dengan 5 Peringkat 2 = Setiap kali ceklist dikalikan dengan 4 Peringkat 3 = Setiap kali ceklist dikalikan dengan 3 Peringkat 4 = Setiap kali ceklist dikalikan dengan 2 Peringkat 5 = Setiap kali ceklist dikalikan dengan 1

Nilai komposit yang telah diperoleh dari mengalikan tiap ceklist kemudian ditentukan bobotnya dengan mempersentasekannya. Adapun bobot/persentase untuk menentukan peringkat komposit keseluruhan komponen sebagai berikut: 
Ihtiyath Vol. 2 No. 2 Desember 2018

\begin{tabular}{ccc}
\hline Tabel 8. Bobot Penetapan Peringkat Komposit \\
\hline Bobot \% & $\begin{array}{c}\text { Peringkat } \\
\text { Komposit }\end{array}$ & Keterangan \\
\hline $86-100$ & PK 1 & Sangat Sehat \\
\hline $71-85$ & PK 2 & Sehat \\
\hline $61-70$ & PK 3 & Cukup Sehat \\
\hline $41-60$ & PK 4 & Kurang Sehat \\
\hline$<40$ & PK 5 & Tidak Sehat \\
\hline
\end{tabular}

Menarik kesimpulan terhadap tingkat kesehatan bank sesuai dengan standar perhitungan kesehatan bank yang telah ditentukan oleh Bank Indonesia berdasarkan perhitungan analisis rasio tersebut pada tabel 8 .

\section{HASIL DAN PEMBAHASAN}

Penetapan Peringkat Komposit Kesehatan Bank pada PT. Bank Rakyat Indonesia, Tbk Tahun 2013

Tabel 9. Penilaian Tingkat Kesehatan PT. Bank Rakyat Indonesia, Tbk

\begin{tabular}{|c|c|c|c|c|c|c|c|c|c|c|}
\hline \multirow{2}{*}{ Tahun } & \multirow{2}{*}{$\begin{array}{c}\text { Komponen } \\
\text { Faktor }\end{array}$} & \multirow{2}{*}{ Rasio } & \multirow{2}{*}{$\begin{array}{c}\text { Rasio } \\
(\%)\end{array}$} & \multicolumn{5}{|c|}{ Peringkat } & \multirow{2}{*}{ Kriteria } & \multirow{2}{*}{$\begin{array}{l}\text { Peringkat } \\
\text { Komposit }\end{array}$} \\
\hline & & & & 1 & 2 & 3 & 4 & 5 & & \\
\hline \multirow{6}{*}{2013} & \multirow{2}{*}{$\begin{array}{l}\text { Profil } \\
\text { Resiko }\end{array}$} & NPL & 1,27 & $\checkmark$ & & & & & Sangat Sehat & \multirow{6}{*}{$\begin{array}{c}\text { PK-1 } \\
\text { (Sangat } \\
\text { Sehat) }\end{array}$} \\
\hline & & LDR & 88,55 & & & $\checkmark$ & & & Cukup Sehat & \\
\hline & $\begin{array}{l}\text { Good } \\
\text { Corporate } \\
\text { Governance }\end{array}$ & GCG & 85,56 & $\checkmark$ & & & & & $\begin{array}{c}\text { Sangat } \\
\text { Terpercaya }\end{array}$ & \\
\hline & \multirow{2}{*}{ Rentabilitas } & ROA & 4,46 & $\checkmark$ & & & & & Sangat Sehat & \\
\hline & & NIM & 7,59 & $\checkmark$ & & & & & Sangat Sehat & \\
\hline & $\begin{array}{l}\text { Permoda- } \\
\text { lan }\end{array}$ & CAR & \multirow{2}{*}{$\begin{array}{c}17,00 \\
30\end{array}$} & \multirow{2}{*}{$\begin{array}{l}\checkmark \\
25\end{array}$} & \multirow[b]{2}{*}{0} & \multirow[b]{2}{*}{3} & \multirow[b]{2}{*}{0} & \multirow[b]{2}{*}{0} & Sangat Sehat & \\
\hline & lilai Komposi & & & & & & & & $(28 / 30) \times 100 \%$ & $93,33 \%$ \\
\hline
\end{tabular}

Sumber: Data diolah, 2018.

Berdasarkan Tabel 9, terlihat bahwa pada tahun 2013 diperoleh Non Performing Loan (NPL) sebesar $1,27 \%$, berarti terdapat 1,27\% dana yang termasuk dalam kredit kurang lan- 
Meutia Dewi: Analisis Tingkat Kesehatan Bank

car, diragukan, dan macet dari total kredit yang diberikan oleh bank. Semakin besar NPL menunjukkan jika bank kurang baik dalam menyeleksi calon peminjam. Hal ini membuktikan bahwa pada tahun 2013 PT. Bank Rakyat Indonesia, Tbk mampu menyeleksi calon peminjamnya dengan sangat baik. Sehingga kemampuan bank dalam menumbuhkan rasa kepercayaan nasabahnya semakin meningkat. Memiliki nilai NPL sebesar 1,27\% dan termasuk dalam predikat sangat sehat atau tingkat komposit 1 karena tidak melebihi batas maksimal yaitu $2 \%$.

Loan to Deposit Ratio (LDR) ditahun 2013 sebesar 88,55\%, berarti setiap dana yang dihimpun bank dapat mendukung pinjaman yang diberikan sebesar 88,55\% dari total kredit yang diberikan. Hal ini membuktikan bahwa pada tahun 2013 PT. Bank Rakyat Indonesia, Tbk dapat mengelola simpanan dalam bentuk kredit hingga mencapai 88,55\%. Sehingga kemampuan menghasilkan laba suatu bank akan meningkat seiring peningkatan pemberian kredit. Memiliki nilai LDR sebesar 88,55\% dan termasuk dalam predikat cukup sehat atau predikat komposit 3 karena tidak melebihi batas maksimal yaitu $100 \%$.

Tahun 2013 Good Corporate Governance (GCG) sebesar 85,56\% dan memperoleh predikat sangat terpercaya berdasarkan hasil pemeringkatan CGPI yang dilakukan oleh lembaga IICG pada laporan tahunan tata kelola perusahaan PT. Bank Rakyat Indonesia, Tbk. Hal ini membuktikan bahwa pada tahun 2013 PT. Bank Rakyat Indonesia, Tbk melakukan manajemen yang baik dan mengikuti prinsip-prinsip GCG sesuai dengan ketentuan yang sudah ditetapkan oleh Peraturan Bank Indonesia.

Return On Asset (ROA) tahun 2013 sebesar 4,46\%, berarti tingkat produktivitas aset dari rata-rata total aset yang digunakan mampu menghasilkan laba sebesar $4,46 \%$. Semakin tinggi persentase maka tingkat produktivitasnya akan semakin meningkat. Hal ini membuktikan bahwa pada tahun 2013 PT. Bank Rakyat Indonesia, Tbk mampu mengelola aset-asetnya dengan sangat baik sehingga dapat menghasilkan laba bersih. Memiliki ROA sebesar $4,46 \%$ dan predikat sangat sehat atau tingkat komposit 1 karena melebihi batas maksimal $1,5 \%$.

Net Interest Margin (NIM) tahun 2013 sebesar 7,59\%, berarti terdapat 7,59\% pendapatan bunga bersih terhadap total aset produktif pada tahun 2013. Semakin tinggi persentase NIM maka tingkat pendapatan bunga bersih akan semakin meningkat. Hal ini membuktikan bahwa pada tahun 2013 PT. Bank Rakyat Indonesia, Tbk mampu melakukan mana- 
Ihtiyath Vol. 2 No. 2 Desember 2018

jemen untuk mengelola aset produktif dengan sangat baik sehingga bisa menghasilkan bunga bersih. Memiliki NIM sebesar 7,59\% dan predikat sangat sehat atau tingkat komposit 1 karena melebihi batas maksimal 3\%.

Tahun 2013 diperoleh Capital Adequacy Ratio (CAR) sebesar 17,00\%, berarti permodalan yang dimiliki bank tersebut dapat mengantisipasi risiko kredit sebesar 17,00\%. Semakin besar persentase maka semakin baik, karena persentase CAR menunjukkan kemampuan permodalan untuk menutupi kemungkinan kegagalan kredit. Sehingga dengan semakin besarnya persentase CAR maka kemampuan modal menutupi kredit semakin baik. Hal ini membuktikan bahwa pada tahun 2013 PT. Bank Rakyat Indonesia, Tbk mampu membiayai berbagai kegiatan operasional dengan sangat baik serta memberikan kontribusi kepada perusahaannya secara maksimal. Memiliki CAR sebesar $17,00 \%$ dan predikat sangat sehat atau tingkat komposit 1 karena melebihi batas minimal yaitu 12\%.

Jadi, tingkat kesehatan PT. Bank Rakyat Indonesia, Tbk pada tahun 2013 dilihat secara keseluruhan termasuk kedalam kategori "Sangat Sehat" atau peringkat komposit 1 (PK-1) dengan memperoleh nilai komposit sebesar 93,33\%. Sehingga PT. Bank Rakyat Indonesia, Tbk dinilai sangat mampu menghadapi pengaruh negatif yang signifikan dari perubahan kondisi bisnis dan faktor eksternal lainnya.

Penetapan Peringkat Komposit Kesehatan Bank pada PT. Bank Rakyat Indonesia, Tbk Tahun 2014

Tabel 10. Penilaian Tingkat Kesehatan PT. Bank Rakyat Indonesia, Tbk

\begin{tabular}{|c|c|c|c|c|c|c|c|c|c|c|}
\hline \multirow{2}{*}{ Tahun } & \multirow{2}{*}{$\begin{array}{c}\text { Komponen } \\
\text { Faktor }\end{array}$} & \multirow{2}{*}{ Rasio } & \multirow{2}{*}{$\begin{array}{c}\text { Rasio } \\
(x)\end{array}$} & \multicolumn{5}{|c|}{ Peringkat } & \multirow{2}{*}{ Kriteria } & \multirow{2}{*}{$\begin{array}{l}\text { Peringkat } \\
\text { Komposit }\end{array}$} \\
\hline & & & & 1 & 2 & 3 & 4 & 5 & & \\
\hline \multirow{7}{*}{2014} & & NPL & 1,25 & $\checkmark$ & & & & & Sangat Sehat & \multirow{6}{*}{$\begin{array}{c}\text { PK-1 } \\
\text { (Sangat } \\
\text { Sehat) }\end{array}$} \\
\hline & Fromit Restivo & IDR & 81,75 & & $\checkmark$ & & & & Sehat & \\
\hline & $\begin{array}{l}\text { Good } \\
\text { Corporate } \\
\text { Covernance }\end{array}$ & GCG & 86,43 & $\checkmark$ & & & & & $\begin{array}{c}\text { Sangat } \\
\text { Terpercaya }\end{array}$ & \\
\hline & \multirow{2}{*}{ Rentabilitas } & ROA & 3,85 & $\checkmark$ & & & & & Sangat Sehat & \\
\hline & & NIM & 6,92 & $\checkmark$ & & & & & Sangat Sehat & \\
\hline & Permodalan & CAR & 18,30 & $\checkmark$ & & & & & Sangat Sehat & \\
\hline & Nilal Komposit & & 30 & 25 & 4 & 0 & 0 & 0 & $(29 / 30) \times 100 z$ & $96,66 x$ \\
\hline
\end{tabular}


Meutia Dewi: Analisis Tingkat Kesehatan Bank

Sumber: Data diolah, 2018.

Berdasarkan Tabel 10, terlihat bahwa pada tahun 2014 diperoleh Non Performing Loan (NPL) sebesar 1,25\%, berarti terdapat 1,25\% dana yang termasuk dalam kredit kurang lancar, diragukan, dan macet dari total kredit yang diberikan oleh bank. Semakin besar NPL menunjukkan jika bank kurang baik dalam menyeleksi calon peminjam. Hal ini membuktikan bahwa pada tahun 2014 PT. Bank Rakyat Indonesia, Tbk mampu menyeleksi calon peminjamnya dengan sangat baik. Sehingga kemampuan bank dalam menumbuhkan rasa kepercayaan nasabahnya semakin meningkat. Pada tahun 2014 bank mengalami penurunan NPL dari 1,27\% ditahun 2013 menurun menjadi 1,25\% ditahun 2014. Memiliki nilai NPL sebesar 1,25\% dan termasuk dalam predikat sangat sehat atau tingkat komposit 1 karena tidak melebihi batas maksimal yaitu $2 \%$.

Loan to Deposit Ratio (LDR) ditahun 2014 sebesar 81,75\%, berarti setiap dana yang dihimpun bank dapat mendukung pinjaman yang diberikan sebesar $81,75 \%$ dari total kredit yang diberikan. Hal ini membuktikan bahwa pada tahun 2014 PT. Bank Rakyat Indonesia, Tbk dapat mengelola simpanan dalam bentuk kredit hingga mencapai 81,75\%. Sehingga kemampuan menghasilkan laba suatu bank akan meningkat seiring peningkatan pemberian kredit. Pada tahun 2014 bank mengalami penurunan dalam hal pemberian kredit dari 88,55\% ditahun 2013 turun menjadi 81,75\% ditahun 2014. Memiliki nilai LDR sebesar 81,75\% dan termasuk dalam predikat sehat atau predikat komposit 2 karena tidak melebihi batas maksimal yaitu $85 \%$.

Tahun 2014 Good Corporate Governance (GCG) sebesar 86,43\% dan memperoleh predikat sangat terpercaya berdasarkan hasil pemeringkatan CGPI yang dilakukan oleh lembaga IICG pada laporan tahunan tata kelola perusahaan PT. Bank Rakyat Indonesia, Tbk. Pada tahun 2014 GCG mengalami kenaikan dari 85,56\% ditahun 2013 meningkat menjadi 86,43\% ditahun 2014. Hal ini membuktikan bahwa pada tahun 2014 PT. Bank Rakyat Indonesia, Tbk melakukan manajemen yang baik dan mengikuti prinsip-prinsip GCG sesuai dengan ketentuan yang sudah ditetapkan oleh Peraturan Bank Indonesia.

Return On Asset (ROA) tahun 2014 sebesar 3,85\%, berarti tingkat produktivitas aset dari rata-rata total aset yang digunakan mampu menghasilkan laba sebesar 3,85\%. Semakin tinggi persentase maka tingkat produktivitasnya akan semakin meningkat. Ditahun 2014 terdapat penurunan tingkat produktivitas aset dari 4,46\% ditahun 2013 menjadi 3,85\% di- 
Ihtiyath Vol. 2 No. 2 Desember 2018

tahun 2014. Hal ini membuktikan bahwa pada tahun 2014 PT. Bank Rakyat Indonesia, Tbk mampu mengelola aset-asetnya dengan sangat baik sehingga dapat menghasilkan laba bersih.Memiliki ROA sebesar 3,85\% dan predikat sangat sehat atau tingkat komposit 1 karena melebihi batas maksimal 1,5\%.

Net Interest Margin (NIM) tahun 2014 sebesar 6,92\%, berarti terdapat 6,92\% pendapatan bunga bersih terhadap total aset produktif pada tahun 2014. Semakin tinggi persentase NIM maka tingkat pendapatan bunga bersih akan semakin meningkat. Ditahun 2014 terjadi penurunan NIM dari 7,59\% ditahun 2013 menjadi 6,29\% ditahun 2014. Hal ini membuktikan bahwa pada tahun 2014 PT. Bank Rakyat Indonesia, Tbk mampu melakukan manajemen untuk mengelola aset produktif dengan sangat baik sehingga bisa menghasilkan bunga bersih. Memiliki NIM sebesar 6,92\% dan predikat sangat sehat atau tingkat komposit 1 karena melebihi batas maksimal 3\%.

Tahun 2014 diperoleh Capital Adequacy Ratio (CAR) sebesar 18,30\%, berarti permodalan yang dimiliki bank tersebut dapat mengantisipasi risiko kredit sebesar 18,30\%. Semakin besar persentase maka semakin baik, karena persentase CAR menunjukkan kemampuan permodalan untuk menutupi kemungkinan kegagalan kredit. Sehingga dengan semakin besarnya persentase CAR maka kemampuan modal menutupi kredit semakin baik. Ditahun 2014 terjadi kenaikan CAR dari 17,00\% ditahun 2013 menjadi 18,30\% ditahun 2014. Hal ini membuktikan bahwa pada tahun 2014 PT. Bank Rakyat Indonesia, Tbk mampu membiayai berbagai kegiatan operasional dengan sangat baik serta memberikan kontribusi kepada perusahaannya secara maksimal. Memiliki CAR sebesar $18,30 \%$ dan predikat sangat sehat atau tingkat komposit 1 karena melebihi batas minimal yaitu $12 \%$.

Jadi, tingkat kesehatan PT. Bank Rakyat Indonesia, Tbk pada tahun 2014 dilihat secara keseluruhan termasuk kedalam kategori "Sangat Sehat" atau peringkat komposit 1 (PK-1) dengan memperoleh nilai komposit sebesar 96,66\%. Sehingga PT. Bank Rakyat Indonesia, Tbk dinilai sangat mampu menghadapi pengaruh negatif yang signifikan dari perubahan kondisi bisnis dan faktor eksternal lainnya.

Penetapan Peringkat Komposit Kesehatan Bank pada PT. Bank Rakyat Indonesia, Tbk Tahun 2015 
Meutia Dewi: Analisis Tingkat Kesehatan Bank

Tabel 11. Penilaian Tingkat Kesehatan PT. Bank Rakyat Indonesia, Tbk

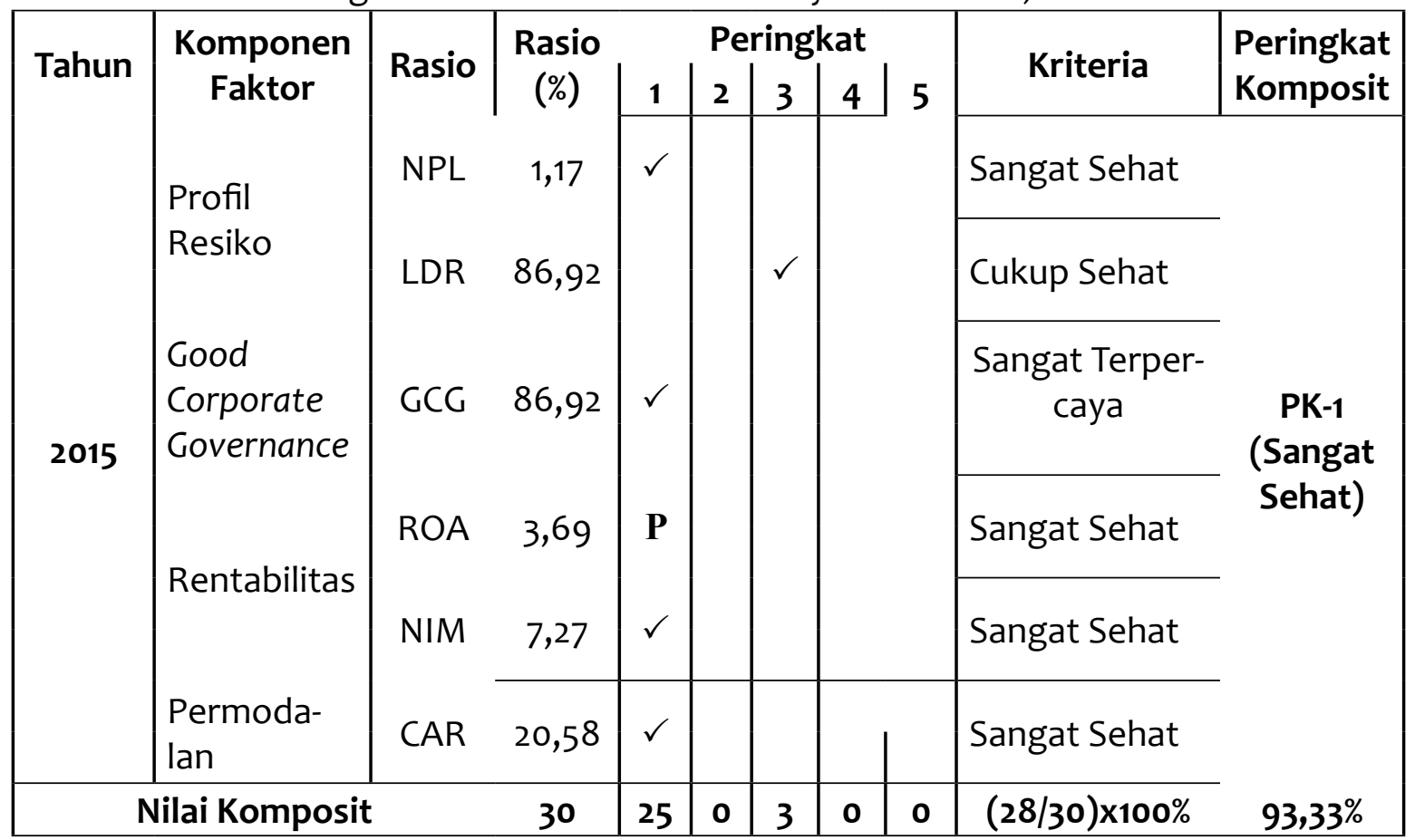

Sumber: Data diolah, 2018.

Berdasarkan Tabel 11, terlihat bahwa pada tahun 2015 diperoleh Non Performing Loan (NPL) sebesar 1,17\% , berarti terdapat 1,17\% dana yang termasuk dalam kredit kurang lancar, diragukan, dan macet dari total kredit yang diberikan oleh bank. Semakin besar NPL menunjukkan jika bank kurang baik dalam menyeleksi calon peminjam. Hal ini membuktikan bahwa pada tahun 2015 PT. Bank Rakyat Indonesia, Tbk mampu menyeleksi calon peminjamnya dengan sangat baik. Sehingga kemampuan bank dalam menumbuhkan rasa kepercayaan nasabahnya semakin meningkat. Pada tahun 2015 bank mengalami penurunan NPL dari 1,25\% ditahun 2014 menurun menjadi 1,17\% ditahun 2015. Memiliki nilai NPL sebesar 1,17\% dan termasuk dalam predikat sangat sehat atau tingkat komposit 1 karena tidak melebihi batas maksimal yaitu $2 \%$.

Loan to Deposit Ratio (LDR) ditahun 2015 sebesar 86,92\%, berarti setiap dana yang dihimpun bank dapat mendukung pinjaman yang diberikan sebesar 86,92\% dari total kredit yang diberikan. Hal ini membuktikan bahwa pada tahun 2015 PT. Bank Rakyat Indonesia, Tbk dapat mengelola simpanan dalam bentuk kredit hingga mencapai 86,92\%. Sehingga kemampuan menghasilkan laba suatu bank akan meningkat seiring peningkatan pemberian kredit. Pada tahun 2015 bank mengalami kenaikan dalam hal pemberian kredit dari 
Ihtiyath Vol. 2 No. 2 Desember 2018

81,75\% ditahun 2014 meningkat menjadi 86,92\% ditahun 2015. Memiliki nilai LDR sebesar $86,92 \%$ dan termasuk dalam predikat cukup sehat atau predikat komposit 3 karena tidak melebihi batas maksimal yaitu $100 \%$.

Tahun 2015 Good Corporate Governance (GCG) sebesar 86,92\% dan memperoleh predikat sangat terpercaya berdasarkan hasil pemeringkatan CGPI yang dilakukan oleh lembaga IICG pada laporan tahunan tata kelola perusahaan PT. Bank Rakyat Indonesia, Tbk. Pada tahun 2015 GCG mengalami kenaikan dari 85,43\% ditahun 2014 meningkat menjadi 86,92\% ditahun 2015. Hal ini membuktikan bahwa pada tahun 2015 PT. Bank Rakyat Indonesia, Tbk melakukan manajemen yang baik dan mengikuti prinsip-prinsip GCG sesuai dengan ketentuan yang sudah ditetapkan oleh Peraturan Bank Indonesia.

Return On Asset (ROA) tahun 2015 sebesar 3,69\%, berarti tingkat produktivitas aset dari rata-rata total aset yang digunakan mampu menghasilkan laba sebesar 3,69\%. Semakin tinggi persentase maka tingkat produktivitasnya akan semakin meningkat. Ditahun 2015 terdapat penurunan tingkat produktivitas aset dari 3,85\% ditahun 2014 menjadi 3,69\% ditahun 2015. Hal ini membuktikan bahwa pada tahun 2015 PT. Bank Rakyat Indonesia, Tbk mampu mengelola aset-asetnya dengan sangat baik sehingga dapat menghasilkan laba bersih. Memiliki ROA sebesar 3,69\% dan predikat sangat sehat atau tingkat komposit 1 karena melebihi batas maksimal $1,5 \%$.

Net Interest Margin (NIM) tahun 2015 sebesar 7,27\%, berarti terdapat 7,27\% pendapatan bunga bersih terhadap total aset produktif pada tahun 2015. Semakin tinggi persentase NIM maka tingkat pendapatan bunga bersih akan semakin meningkat. Ditahun 2015 terjadi kenaikan NIM dari 6,29\% ditahun 2014 menjadi 7,27\% ditahun 2015. Hal ini membuktikan bahwa pada tahun 2015 PT. Bank Rakyat Indonesia, Tbk mampu melakukan manajemen untuk mengelola aset produktif dengan sangat baik sehingga bisa menghasilkan bunga bersih. Memiliki NIM sebesar 7,27\% dan predikat sangat sehat atau tingkat komposit 1 karena melebihi batas maksimal 3\%.

Tahun 2015 diperoleh Capital Adequacy Ratio (CAR) sebesar 20,58\%, berarti permodalan yang dimiliki bank tersebut dapat mengantisipasi risiko kredit sebesar 20,58\%. Semakin besar persentase maka semakin baik, karena persentase CAR menunjukkan kemampuan permodalan untuk menutupi kemungkinan kegagalan kredit. Sehingga dengan semakin besarnya persentase CAR maka kemampuan modal menutupi kredit semakin baik. Dita- 
Meutia Dewi: Analisis Tingkat Kesehatan Bank

hun 2015 terjadi kenaikan CAR dari 18,30\% ditahun 2014 menjadi 20,58\% ditahun 2015. Hal ini membuktikan bahwa pada tahun 2015 PT. Bank Rakyat Indonesia, Tbk mampu membiayai berbagai kegiatan operasional dengan sangat baik serta memberikan kontribusi kepada perusahaannya secara maksimal. Memiliki CAR sebesar 20,58\% dan predikat sangat sehat atau tingkat komposit 1 karena melebihi batas minimal yaitu $12 \%$.

Jadi, tingkat kesehatan PT. Bank Rakyat Indonesia, Tbk pada tahun 2015 dilihat secara keseluruhan termasuk kedalam kategori "Sangat Sehat" atau peringkat komposit 1 (PK-1) dengan memperoleh nilai komposit sebesar 93,33\%. Sehingga PT. Bank Rakyat Indonesia, Tbk dinilai sangat mampu menghadapi pengaruh negatif yang signifikan dari perubahan kondisi bisnis dan faktor eksternal lainnya.

Penetapan Peringkat Komposit Kesehatan Bank pada PT. Bank Rakyat Indonesia, Tbk Tahun 2016

Tabel 12. Penilaian Tingkat Kesehatan PT. Bank Rakyat Indonesia, Tbk

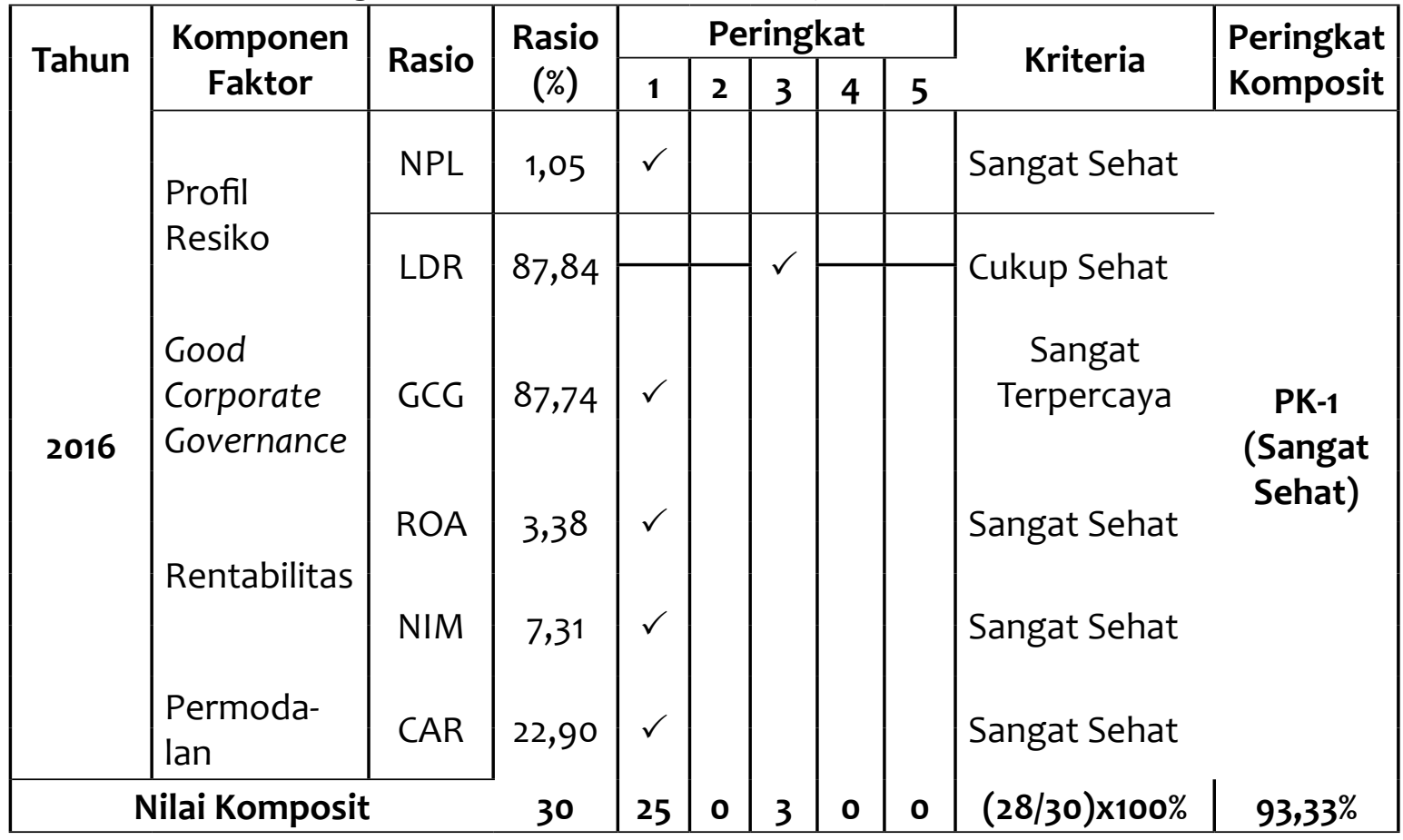

Sumber: Data diolah, 2018.

Berdasarkan Tabel 12, terlihat bahwa pada tahun 2016 diperoleh Non Performing Loan (NPL) sebesar 1,05\%, berarti terdapat 1,05\% dana yang termasuk dalam kredit kurang 
Ihtiyath Vol. 2 No. 2 Desember 2018

lancar, diragukan, dan macet dari total kredit yang diberikan oleh bank. Semakin besar NPL menunjukkan jika bank kurang baik dalam menyeleksi calon peminjam. Hal ini membuktikan bahwa pada tahun 2016 PT. Bank Rakyat Indonesia, Tbk mampu menyeleksi calon peminjamnya dengan sangat baik. Sehingga kemampuan bank dalam menumbuhkan rasa kepercayaan nasabahnya semakin meningkat. Pada tahun 2016 bank mengalami penurunan NPL dari 1,17\% ditahun 2015 menurun menjadi 1,05\% ditahun 2016. Memiliki nilai NPL sebesar 1,05\% dan termasuk dalam predikat sangat sehat atau tingkat komposit 1 karena tidak melebihi batas maksimal yaitu $2 \%$.

Loan to Deposit Ratio (LDR) ditahun 2016 sebesar 87,84\%, berarti setiap dana yang dihimpun bank dapat mendukung pinjaman yang diberikan sebesar $87,84 \%$ dari total kredit yang diberikan. Hal ini membuktikan bahwa pada tahun 2016 PT. Bank Rakyat Indonesia, Tbk dapat mengelola simpanan dalam bentuk kredit hingga mencapai 87,84\%. Sehingga kemampuan menghasilkan laba suatu bank akan meningkat seiring peningkatan pemberian kredit. Pada tahun 2016 bank mengalami kenaikan dalam hal pemberian kredit dari 86,92\% ditahun 2015 meningkat menjadi 87,84\% ditahun 2016. Memiliki nilai LDR sebesar $87,84 \%$ dan termasuk dalam predikat cukup sehat atau predikat komposit 3 karena tidak melebihi batas maksimal yaitu $100 \%$.

Tahun 2016 Good Corporate Governance (GCG) sebesar 87,74\% dan memperoleh predikat sangat terpercaya berdasarkan hasil pemeringkatan CGPI yang dilakukan oleh lembaga IICG pada laporan tahunan tata kelola perusahaan PT. Bank Rakyat Indonesia, Tbk. Pada tahun 2016 GCG mengalami kenaikan dari 86,92\% ditahun 2015 meningkat menjadi 87,74\% ditahun 2016. Hal ini membuktikan bahwa pada tahun 2016 PT. Bank Rakyat Indonesia, Tbk melakukan manajemen yang baik dan mengikuti prinsip-prinsip GCG sesuai dengan ketentuan yang sudah ditetapkan oleh Peraturan Bank Indonesia.

Return On Asset (ROA) tahun 2016 sebesar 3,38\%, berarti tingkat produktivitas aset dari rata-rata total aset yang digunakan mampu menghasilkan laba sebesar 3,38\%. Semakin tinggi persentase maka tingkat produktivitasnya akan semakin meningkat. Ditahun 2016 terdapat penurunan tingkat produktivitas aset dari 3,69\% ditahun 2015 menjadi 3,38\% ditahun 2016. Hal ini membuktikan bahwa pada tahun 2016 PT. Bank Rakyat Indonesia, Tbk mampu mengelola aset-asetnya dengan sangat baik sehingga dapat menghasilkan laba bersih. Memiliki ROA sebesar 3,38\% dan predikat sangat sehat atau tingkat komposit 1 karena melebihi batas maksimal $1,5 \%$. 
Meutia Dewi: Analisis Tingkat Kesehatan Bank

Net Interest Margin (NIM) tahun 2016 sebesar 7,31\%, berarti terdapat 7,31\% pendapatan bunga bersih terhadap total aset produktif pada tahun 2016. Semakin tinggi persentase NIM maka tingkat pendapatan bunga bersih akan semakin meningkat. Ditahun 2016 terjadi kenaikan NIM dari 7,27\% ditahun 2015 menjadi 7,31\% ditahun 2016. Hal ini membuktikan bahwa pada tahun 2016 PT. Bank Rakyat Indonesia, Tbk mampu melakukan manajemen untuk mengelola aset produktif dengan sangat baik sehingga bisa menghasilkan bunga bersih. Memiliki NIM sebesar 7,31\% dan predikat sangat sehat atau tingkat komposit 1 karena melebihi batas maksimal 3\%.

Tahun 2016 diperoleh Capital Adequacy Ratio (CAR) sebesar 22,90\%, berarti permodalan yang dimiliki bank tersebut dapat mengantisipasi risiko kredit sebesar $22,90 \%$. Semakin besar persentase maka semakin baik, karena persentase CAR menunjukkan kemampuan permodalan untuk menutupi kemungkinan kegagalan kredit. Sehingga dengan semakin besarnya persentase CAR maka kemampuan modal menutupi kredit semakin baik. Ditahun 2016 terjadi kenaikan CAR dari 20,58\% ditahun 2015 menjadi 22,90\% ditahun 2016. Hal ini membuktikan bahwa pada tahun 2016 PT. Bank Rakyat Indonesia, Tbk mampu membiayai berbagai kegiatan operasional dengan sangat baik serta memberikan kontribusi kepada perusahaannya secara maksimal. Memiliki CAR sebesar 22,90\% dan predikat sangat sehat atau tingkat komposit 1 karena melebihi batas minimal yaitu $12 \%$.

Jadi, tingkat kesehatan PT. Bank Rakyat Indonesia, Tbk pada tahun 2016 dilihat secara keseluruhan termasuk kedalam kategori "Sangat Sehat" atau peringkat komposit 1 (PK-1) dengan memperoleh nilai komposit sebesar 93,33\%. Sehingga PT. Bank Rakyat Indonesia, Tbk dinilai sangat mampu menghadapi pengaruh negatif yang signifikan dari perubahan kondisi bisnis dan faktor eksternal lainnya.

Penetapan Peringkat Komposit Kesehatan Bank pada PT. Bank Rakyat Indonesia, Tbk Tahun 2017

Tabel 13. Penilaian Tingkat Kesehatan PT. Bank Rakyat Indonesia, Tbk

\begin{tabular}{|c|c|c|c|c|c|c|c|c|c|c|}
\hline \multirow{2}{*}{ Tahun } & $\begin{array}{c}\text { Komponen } \\
\text { Faktor }\end{array}$ & Rasio & $\begin{array}{c}\text { Rasio } \\
(\%)\end{array}$ & \multicolumn{4}{|c|}{ Peringkat } & Kriteria & Peringkat \\
& Komposit \\
\hline
\end{tabular}


Ihtiyath Vol. 2 No. 2 Desember 2018

\begin{tabular}{|c|c|c|c|c|c|c|c|c|c|c|}
\hline \multirow{10}{*}{2017} & \multirow{2}{*}{$\begin{array}{l}\text { Profil } \\
\text { Resiko }\end{array}$} & NPL & 1,10 & $\checkmark$ & & & & & Sangat Sehat & \multirow{10}{*}{$\begin{array}{c}\text { PK-1 } \\
\text { (Sangat } \\
\text { Sehat) }\end{array}$} \\
\hline & & LDR & 88,18 & & & $\checkmark$ & & & Cukup Sehat & \\
\hline & \multirow{3}{*}{$\begin{array}{l}\text { Good } \\
\text { Corporate } \\
\text { Governance }\end{array}$} & \multirow{3}{*}{ GCG } & \multirow{3}{*}{88,48} & \multirow{3}{*}{$\checkmark$} & & & & & \multirow{3}{*}{$\begin{array}{c}\text { Sangat } \\
\text { Terpercaya }\end{array}$} & \\
\hline & & & & & & & & & & \\
\hline & & & & & & & & & & \\
\hline & \multirow{3}{*}{ Rentabilitas } & ROA & 3,20 & $\checkmark$ & & & & & \multirow{2}{*}{ Sangat Sehat } & \\
\hline & & & & & & & & & & \\
\hline & & NIM & 7,02 & $\checkmark$ & & & & & Sangat Sehat & \\
\hline & \multirow{2}{*}{$\begin{array}{l}\text { Permoda- } \\
\text { lan }\end{array}$} & \multirow{2}{*}{ CAR } & \multirow{2}{*}{22,96} & \multirow{2}{*}{$\checkmark$} & & & & & \multirow{2}{*}{ Sangat Sehat } & \\
\hline & & & & & & & & & & \\
\hline \multicolumn{3}{|c|}{ Nilai Komposit } & 30 & 25 & 0 & 3 & $\mathbf{0}$ & 0 & $(28 / 30) \times 100 \%$ & $93,33 \%$ \\
\hline
\end{tabular}

Sumber: Data diolah, 2018.

Berdasarkan Tabel 13, terlihat bahwa pada tahun 2017 diperoleh Non Performing Loan (NPL) sebesar 1,10\% , berarti terdapat 1,10\% dana yang termasuk dalam kredit kurang lancar, diragukan, dan macet dari total kredit yang diberikan oleh bank. Semakin besar NPL menunjukkan jika bank kurang baik dalam menyeleksi calon peminjam. Hal ini membuktikan bahwa pada tahun 2017 PT. Bank Rakyat Indonesia, Tbk mampu menyeleksi calon peminjamnya dengan sangat baik. Sehingga kemampuan bank dalam menumbuhkan rasa kepercayaan nasabahnya semakin meningkat. Pada tahun 2017 bank mengalami kenaikan NPL dari 1,05\% ditahun 2016 menurun menjadi 1,10\% ditahun 2017. Memiliki nilai NPL sebesar 1,10\% dan termasuk dalam predikat sangat sehat atau tingkat komposit 1 karena tidak melebihi batas maksimal yaitu $2 \%$.

Loan to Deposit Ratio (LDR) ditahun 2017 sebesar 88,18\%, berarti setiap dana yang dihimpun bank dapat mendukung pinjaman yang diberikan sebesar 88,18\% dari total kredit yang diberikan. Hal ini membuktikan bahwa pada tahun 2017 PT. Bank Rakyat Indonesia, Tbk dapat mengelola simpanan dalam bentuk kredit hingga mencapai 88,18\%. Sehingga kemampuan menghasilkan laba suatu bank akan meningkat seiring peningkatan pemberian kredit. Pada tahun 2017 bank mengalami kenaikan dalam hal pemberian kredit dari 87,84\% ditahun 2016 meningkat menjadi 88,18\% ditahun 2017. Memiliki nilai LDR sebesar $88,18 \%$ dan termasuk dalam predikat cukup sehat atau predikat komposit 3 karena tidak melebihi batas maksimal yaitu $100 \%$. 
Meutia Dewi: Analisis Tingkat Kesehatan Bank

Tahun 2017 Good Corporate Governance (GCG) sebesar 88,48\% dan memperoleh predikat sangat terpercaya berdasarkan hasil pemeringkatan CGPI yang dilakukan oleh lembaga IICG pada laporan tahunan tata kelola perusahaan PT. Bank Rakyat Indonesia, Tbk. Pada tahun 2017 GCG mengalami kenaikan dari 87,74\% ditahun 2016 meningkat menjadi 88,48\% ditahun 2017. Hal ini membuktikan bahwa pada tahun 2017 PT. Bank Rakyat Indonesia, Tbk melakukan manajemen yang baik dan mengikuti prinsip-prinsip GCG sesuai dengan ketentuan yang sudah ditetapkan oleh Peraturan Bank Indonesia.

Return On Asset (ROA) tahun 2017 sebesar 3,29\%, berarti tingkat produktivitas aset dari rata-rata total aset yang digunakan mampu menghasilkan laba sebesar 3,29\%. Semakin tinggi persentase maka tingkat produktivitasnya akan semakin meningkat. Ditahun 2017 terdapat penurunan tingkat produktivitas aset dari 3,38\% ditahun 2016 menjadi 3,29\% ditahun 2017. Hal ini membuktikan bahwa pada tahun 2017 PT. Bank Rakyat Indonesia, Tbk mampu mengelola aset-asetnya dengan sangat baik sehingga dapat menghasilkan laba bersih. Memiliki ROA sebesar 3,29\% dan predikat sangat sehat atau tingkat komposit 1 karena melebihi batas maksimal $1,5 \%$.

Net Interest Margin (NIM) tahun 2017 sebesar 7,02\%, berarti terdapat 7,02\% pendapatan bunga bersih terhadap total aset produktif pada tahun 2017. Semakin tinggi persentase NIM maka tingkat pendapatan bunga bersih akan semakin meningkat. Ditahun 2017 terjadi penurunan NIM dari 7,31\% ditahun 2016 menjadi 7,02\% ditahun 2017. Hal ini membuktikan bahwa pada tahun 2017 PT. Bank Rakyat Indonesia, Tbk mampu melakukan manajemen untuk mengelola aset produktif dengan sangat baik sehingga bisa menghasilkan bunga bersih. Memiliki NIM sebesar 7,02\% dan predikat sangat sehat atau tingkat komposit 1 karena melebihi batas maksimal 3\%.

Tahun 2017 diperoleh Capital Adequacy Ratio (CAR) sebesar 22,96\%, berarti permodalan yang dimiliki bank tersebut dapat mengantisipasi risiko kredit sebesar 22,96\%. Semakin besar persentase maka semakin baik, karena persentase CAR menunjukkan kemampuan permodalan untuk menutupi kemungkinan kegagalan kredit. Sehingga dengan semakin besarnya persentase CAR maka kemampuan modal menutupi kredit semakin baik. Ditahun 2017 terjadi kenaikan CAR dari 22,90\% ditahun 2016 menjadi 22,96\% ditahun 2017. Hal ini membuktikan bahwa pada tahun 2017 PT. Bank Rakyat Indonesia, Tbk mampu membiayai berbagai kegiatan operasional dengan sangat baik serta memberikan kontribusi kepada perusahaannya secara maksimal. Memiliki CAR sebesar 22,96\% dan predikat san- 
Ihtiyath Vol. 2 No. 2 Desember 2018

gat sehat atau tingkat komposit 1 karena melebihi batas minimal yaitu $12 \%$.

Jadi, tingkat kesehatan PT. Bank Rakyat Indonesia, Tbk pada tahun 2017 dilihat secara keseluruhan termasuk kedalam kategori "Sangat Sehat" atau peringkat komposit 1 (PK-1) dengan memperoleh nilai komposit sebesar 93,33\%. Sehingga PT. Bank Rakyat Indonesia, Tbk dinilai sangat mampu menghadapi pengaruh negatif yang signifikan dari perubahan kondisi bisnis dan faktor eksternal lainnya.

Tabel 14. Peringkat Komposit PT. Bank Rakyat Indonesia, Tbk Periode 2013-2017

\begin{tabular}{|c|c|c|c|}
\hline Tahun & $\begin{array}{c}\text { Nilai } \\
\text { Komposit } \\
93,33 \%\end{array}$ & $\begin{array}{c}\text { Peringkat } \\
\text { Komposit } \\
\text { PK 1 }\end{array}$ & Keterangan \\
2013 & $96,66 \%$ & PK 1 & Sangat Sehat \\
\hline 2014 & $93,33 \%$ & PK 1 & Sangat Sehat \\
\hline 2015 & $93,33 \%$ & PK 1 & Sangat Sehat \\
\hline 2016 & $93,33 \%$ & PK 1 & Sangat Sehat \\
\hline 2017 & $93,99 \%$ & PK 1 & Sangat Sehat \\
\hline Rata-rata & & & \\
\hline
\end{tabular}

Sumber: Data diolah, 2018.

Berdasarkan Tabel 14, dapat disimpulkan bahwa tingkat kesehatan pada PT. Bank Rakyat Indonesia dari tahun 2013 sampai dengan 2017 mendapatkan peringkat komposit 1(PK-1) atau "Sangat Sehat" yang mencerminkan kondisi bank yang secara umum sangat sehat, sehingga dinilai sangat mampu menghadapi pengaruh negatif yang signifikan dari perubahan kondisi bisnis dan faktor eksternal lainnya.

\section{KESIMPULAN DAN SARAN Kesimpulan}

Dari hasil analisis data dan pembahasan maka kesimpulan dalam penelitian ini adalah sebagai berikut:

Penilaian tingkat kesehatan bank pada PT. Bank Rakyat Indonesia, Tbk dilihat dari faktor risk profile pada periode 2013 mendapatkan peringkat komposit 2 (PK-2) atau "Sehat", periode 2014 mendapatkan peringkat komposit 1 (PK-1) atau "Sangat Sehat", periode 2015 mendapatkan peringkat komposit 2 (PK-2) atau "Sehat", periode 2016 mendapatkan peringkat komposit 2 (PK-2) atau "Sehat", dan periode 2017 mendapatkan peringkat komposit 2 (PK-2) atau "Sehat". 
Meutia Dewi: Analisis Tingkat Kesehatan Bank

Penilaian tingkat kesehatan bank pada PT. Bank Rakyat Indonesia, Tbk dilihat dari faktor good corporate governance pada periode 2013 mendapatkan peringkat komposit 1 (PK-1) atau "Sangat Terpercaya", periode 2014 mendapatkan peringkat komposit 1 (PK-1) atau "Sangat Terpercaya", periode 2015 mendapatkan peringkat komposit 1 (PK-1) atau "Sangat Terpercaya", periode 2016 mendapatkan peringkat komposit 1 (PK-1) atau "Sangat Terpercaya", dan periode 2017 mendapatkan peringkat komposit 1 (PK-1) atau "Sangat Sehat".

Penilaian tingkat kesehatan bank pada PT. Bank Rakyat Indonesia, Tbk dilihat dari faktor earning pada periode 2013-2017 mendapatkan peringkat komposit 1(PK-1) atau "Sangat Sehat".

Penilaian tingkat kesehatan bank pada PT. Bank Rakyat Indonesia, Tbk dilihat dari faktor capital pada periode 2013- 2017 mendapatkan peringkat komposit 1 (PK-1) atau "Sangat Sehat".

Penilaian tingkat kesehatan bank pada PT. Bank Rakyat Indonesia, Tbk dilihat dari faktor risk profile, good corporate governance, earning, dan capital dari tahun 2013, 2014, 2015, 2016, dan 2017 mendapatkan peringkat komposit 1 (PK-1) atau "Sangat Sehat", sehingga dinilai sangat mampu menghadapi pengaruh negatif yang signifikan dari perubahan kondisi bisnis dan faktor eksternal lainnya.

\section{Saran}

Dari hasil analisis data, pembahasan, dan kesimpulan maka saran yang dapat penulis berikan yaitu:

PT. Bank Rakyat Indonesia hendaknya mampu memperbaiki nilai rasio-rasio untuk mengukur tingkat kesehatan bank pada tahun-tahun berikutnya. Terutama pada faktor Risk Profile dalam hal risiko likuiditas dalam perhitungan rasio LDR yang masih berada dalam kategori cukup sehat secara keseluruhan. PT. Bank Rakyat Indonesia, Tbk hendaknya mampu menarik minat nasabahnya untuk menabung dengan cara mengadakan promosi atau membuat inovasi produk baru. Selain itu, penyaluran dana dalam bentuk kredit kepada pihak nasabah harus lebih selektif dalam memilih nasabah penerima kredit agar pihak bank dapat memenuhi kewajibannya. 
Ihtiyath Vol. 2 No. 2 Desember 2018

Pada faktor rentabilitas dalam perhitungan rasio ROA dan NIM yang memiliki penurunan nilai rentabilitas dari tahun ke tahun. PT. Bank Rakyat Indonesia, Tbk hendaknya mampu untuk mengelola asetnya lebih maksimal dengan memanfaatkan pemberian kredit kepada nasabahnya lebih banyak lagi dan lebih menekankan biaya operasional sehingga mampu meningkatkan laba secara maksimal dalam kegiatan operasional perusahaan.

PT. Bank Rakyat Indonesia, Tbk hendaknya mampu mempertahankan kesehatan bank pada tahun-tahun berikutnya. Kesehatan bank dengan peringkat komposit sangat sehat akan meningkatkan kepercayaan masyarakat, nasabah, investor, dan pihak terkait lainnya.

PT. Bank Rakyat Indonesia, Tbk hendaknya mampu mempertahankan kesehatan banknya tidak hanya berfokus pada laporan keuangan, tetapi juga perlu untuk mengembangkan usaha dengan pelayanan yang diberikan agar lebih aman, mudah, dan juga cepat. Selain itu, pengaruh negatif yang signifikan dari perubahan kondisi bank bisnis dan faktor eksternal lainnya hendaknya menjadi tolak ukur dalam menyusun anggaran tahun berikutnya.

Bagi peneliti selanjutnya, disarankan untuk memperluas cakupan penilitian tentang penilaian kesehatan bank dengan menggunakan indikator rasio keuangan lainnya pada pengukuran tingkat kesehatan bank.

\section{DAFTAR PUSTAKA}

Anan, E. dan Albarqis, R.. 2017. “ Tingkat Kesehatan Bank dengan Pendekatan RGEC pada Bank Pembangunan Daerah DIY”. JRAK. Vol. 13. No. 2. Hal. 117-132.

Arikunto, S.. 2010. Prosedur Penelitian: Suatu Pendekatan Praktik. Edisi Revisi. Jakarta: Rineka Cipta.

Bank Indonesia. 2004. Peraturan Bank Indonesia No.6/10/PBI/2004 tentang Sistem Penilaian Tingkat Kesehatan Bank Umum. diunduh pada tanggal 17 Februari 2018 dari https://www.bi.go.id/id/peraturan/arsip-peraturan/Perbankan2004/pbi_61004.pdf

Bank Indonesia. 2004. Surat Edaran Bank Indonesia No.6/23/DPNP/2004 tentang Sistem Penilaian Tingkat Kesehatan Bank Umum. diunduh pada 17 Februari 2018 dari https://www.bi.go.id/id/peraturan/perbankan /Pages/ketentuan\%2operbankan. aspx 
Meutia Dewi: Analisis Tingkat Kesehatan Bank

Bank Indonesia. 2011. Peraturan Bank Indonesia No.13/1/PBI/2011 tentang Prosedur dan Mekanisme Penilaian Tingkat Kesehatan Bank. diunduh pada tanggal 17 Februari 2018 dari https://www.bi.go.id/id/peraturan/perbankan/Pages/pbi_130111.aspx

Bank Indonesia. 2011. Surat Edaran Bank Indonesia No.13/24/DPNP/2011 tentang Penilaian Tingkat Kesehatan Bank Umum. diunduh pada tanggal 17 Februari 2018 dari https:// www.bi.go.id/id/peraturan/perbankan/Pages/SE\%20No.13_24_DPNP_2011.aspx

Bank Indonesia. 2012. Laporan Pengawasan Perbankan 2012. diunduh pada tanggal 17 Februari 2018 dari https://www.bi.go.id/id/publikasi /perbankan-dan-stabilitas/ laporan-pengawasan/Default.aspx

Bank Indonesia. 2013. Surat Edaran Bank Indonesia No.15/15/DPNP/2013 tentang Pelaksanaan Good Corporate Governance pada Bank Umum. diunduh pada tanggal 17 Februari 2018 dari https://www.bi.go.id/id/peraturan/perbankan/Pages/SE_15_15DPNP.aspx

Http://www.ir-bri.com/ar.html

Http://www.idx.co.id/perusahaan-tercatat/laporan-keuangan-dan-tahunan/

Kasmir. 2014. Manajemen Perbankan. Edisi Revisi. Jakarta: Rajawali Pers.

Kuncoro, Mudrajad. 2009. Metode Riset untuk Bisnis \& Ekonomi Edisi ke tiga. Jakarta: PT. Gelora Aksara Pratama.

Lasta, H. A., Arifin, Z., dan Nuzula, N. F.. 2014. "Analisis Tingkat Kesehatan Bank dengan Menggunakan Pendekatan RGEC (Risk Profile, Good Corporate Governance, Earnings, Capital) (Studi pada PT. Bank Rakyat Indonesia, Tbk Periode 2011-2013)". Jurnal Administrasi Bisnis (JAB). Vol. 13. No. 2. Hal. 1-10.

Martono, N.. 2011. Metode Penelitian Kuantitatif. Jakarta: PT Rajagrafindo Persada.

Minarrohmah, K., Yaningwati, F., dan Nuzula, N. F.. 2014. “Analisis Tingkat Kesehatan Bank dengan Menggunakan Pendekatan RGEC (Risk Profile, Good Corporate Governance, Earnings, Capital) (Studi pada PT. Bank Central Asia, Tbk Periode 20102012)". Jurnal Administrasi Bisnis (JAB). Vol. 17. No. 1. Hal. 1-9.

Otoritas Jasa Keuangan. 2017. Surat Edaran Otoritas Jasa Keuangan No.14/SEOJK.03/2017 tentang Penilaian Tingkat Kesehatan Bank Umum. diunduh pada 17 Februari 2018 dari https://www.ojk.go.id/id/kanal/perbankan/regulasi/surat-edaran-ojk/Pages/ Surat-Edaran-Otoritas-Jasa-Keuangan-Nomor-14-SEOJK.03-2017.aspx 
Ihtiyath Vol. 2 No. 2 Desember 2018

Refmasari, V. A. dan Setiawan, N.. 2014. "Penilaian Tingkat Kesehatan Bank Umum Menggunakan Metode RGEC Dengan Cakupan Risk Profile, Earnings, dan Capital Pada Bank Pembangunan Daerah Provinsi Daerah Istimewa Yogyakarta Tahun 2012". Jurnal Profita. Vol.2. No.1. Hal. 41-54.

Sugiyono. 2009. Metode Penelitian Kuantitatif Kualitatif dan R\&D. Bandung: Alfabeta.

Undang-Undang Nomor 10 Tahun 1998 tentang Perubahan Atas Undang-Undang Nomor 7 Tahun 1992 tentang Perbankan.

Wardiah, M. L.. 2013. Dasar-Dasar Perbankan. Bandung: CV Pustaka Setia.

Yessi, N. P., Rahayu, S. M., dan Endang, M. G.. 2015. “ Analisis Tingkat Kesehatan Bank dengan Menggunakan Pendekatan RGEC (Risk Profile, Good Corporate Governance, Earnings, Capital) Studi pada PT Bank Sinar Harapan Bali Periode 2010-2012". Jurnal Administrasi Bisnis (JAB). Vol. 1. No. 1. Hal. 1-8. 